\title{
Pengaruh Kompetensi Pedagogik Guru terhadap Kualitas Pembelajaran Sekolah Menengah Atas di Kota Sekayu, Sumatera Selatan
}

\author{
Amrina Rosyada ${ }^{1 *}$, Edi Harapan², Rohana ${ }^{2}$ \\ ${ }^{1}$ SMA Negeri 4 Sekayu, Musi Banyuasin, Sumatera Selatan, Indonesia \\ ${ }^{2}$ Universitas PGRI Palembang, Palembang, Sumatera Selatan, Indonesia \\ Corresponding author: Amrina Rosyada (e-mail: rosyadaa024@gmail.com)
}

\begin{abstract}
Abstrak: Penelitian ini bertujuan untuk mengetahui pengaruh kompetensi pedagogik guru terhadap kualitas pembelajaran. Metode penelitian yang digunakan pada kajian ini adalah survei dengan pendekatan kuantitatif. Populasi dalam penelitian ini adalah guru sekolah menengah atas negeri (SMAN) di Kota Sekayu, Provinsi Sumatera Selatan. Jumlah populasi yaitu 162 orang dengan sampel sebanyak 102 orang yang dipilih dengan menggunakan teknik random sampling. Data dikumpulkan menggunakan angket. Validasi instrumen dilakukan dengan uji validitas dan uji reliabilitas. Teknik analisis data dilakukan dengan analisis koefisien determinasi, uji signifikansi (uji t), dan persamaan regresi linier sederhana. Hasil penelitian ini menunjukkan bahwa kompetensi pedagogik guru berpengaruh signifikan terhadap kualitas pembelajaran dengan nilai koefisien sebesar 0,295. Hasil penelitian ini menyarankan penguatan kompetensi pedagogik guru sebagai bagian dari upaya peningkatan kualitas pembelajaran.
\end{abstract}

Kata Kunci: kualitas pembelajaran, kompetensi pedagogik guru

\section{The Influence of Teachers' Pedagogical Competence on Learning Quality}

Abstract: This study aimed to determine the influence of teachers' pedagogical competence on learning quality. The research method used in this study is a survey with a quantitative approach. The population was the teachers of public senior high schools in Sekayu City, South Sumatera Province. The population was 162 teachers, 102 of them were selected using random sampling technique. The data was collected using a questionnaire. The instrument validation is achieved through a validity test and reliability test. The data analysis techniques are performed with the determination coefficient analysis, significant test (t-test), and simple linear regression. This study showed that the teachers' pedagogical competence significantly influenced the quality of learning with a coefficient value of 0.295. This study suggests strengthening teachers' pedagogical competence as part of efforts to improve the quality of learning.

Keywords: learning quality, teachers' pedagogical competence 


\section{PENDAHULUAN}

Pendidikan merupakanfaktor utama dalam upaya pengembangan kecerdasan, penguasaan ilmu pengetahuan, dan pembentukan kepribadian manusia. Sistem pendidikan yang baik diharapkan dapat melahirkan generasi penerus bangsa yang berkualitas. Pembenahan pendidikan merupakan respon terhadap perkembangan global. Pembenahan pendidikan yang dimulai sejak tahun 1998 diarahkan kepada wawasan masa depan dengan memberikan jaminan bagi terwujudnya hak-hak asasi manusia untuk mengembangkan seluruh potensi dirinya secara optimal guna kesejahteraan hidupnya di masa depan (Sudrajat, 2008). Selain itu, kemajuan pendidikan dapat dilihat dari kemampuan dan kemauan masyarakat memproses informasi dan beradaptasi dengan kemajuan teknologi.

Kemajuan teknologi, khususnya pada bidang pendidikan, telah membawa setiap lembaga pendidikan mengarah kepada kualitas pembelajaran di sekolah. Peraturan Pemerintah Nomor 19 tahun 2005 tentang Standar Nasional Pendidikan (SNP) telah menetapkan delapan standar pendidikan, termasuk di dalamnya standar pembelajaran. Kebijakan ini bertujuan agar sekolah mampu memenuhi standar dan jika memungkinkan melebihinya. Sekolah yang mampu menerapkan pembelajaran melebihi standar pendidikan disebut sebagai sekolah yang berkualitas. Sekolah tersebut, proses pembelajarannya tentu saja berkualitas.

Pembelajaran yang berkualitas membutuhkan partisipasi dari berbagai pihak. Hal tersebut dapat terwujud ketika semua komponen pendidikan melampaui SNP. Indikatornya yaitu kurikulum yang sesuai dengan kebutuhan masyarakat (K-13), kualifikasi pendidikan guru yang melampaui standar, cara guru mengajar yang fleksibel, sarana dan prasarana memadai, biaya pendidikan terpenuhi, seleksi masuk peserta didik yang ketat, dan lulusan yang berkualitas. Institusi pendidikan juga perlu melakukan peningkatan kompetensi guru melalui seminar, pelatihan, dan workshop secara berkelanjutan (Saifulloh, dkk., 2012).

Guru sebagai salah satu unsur kualitas pendidikan harus mampu menjadi motivator, fasilitator, pembimbing, dan innovator. Hal tersebut merupakan paradigma baru dalam metodologi pembelajaran bagi guru. Menurut Harapan (2007), kehadiran guru sebagai pendidik di sekolah tidak dapat digantikan dengan media apapun. Hal ini menunjukkan betapa pentingnya kehadiran guru di sekolah. Paradigma ini, disadari atau tidak, telah menuntut guru memenuhi persyaratan dan kompetensi untuk dapat melakukan suatu perubahan dalam melaksanakan proses pembelajaran di kelas.

Menurut Undang-Undang Nomor 14 Tahun 2005 tentang Guru dan Dosen, salah satu kompetensi yang harus dimiliki oleh seorang guru adalah pedagogik. Kompetensi pedagogik merupakan kemampuan seorang guru mengelola proses pembelajaran yang berhubungan 
dengan peserta didik. Kemampuan ini meliputi pemahaman tentang landasan kependidikan dan peserta didik, pengembangan kurikulum dan silabus, perancangan dan pelaksanaan pembelajaran yang bersifat dialogis, pemanfaatan teknologi pembelajaran, evaluasi hasil belajar, dan pengembangan peserta didik untuk mengaktualisasikan berbagai potensi yang dimilikinya. Kompetensi pedagogik merupakan modal utama bagi guru untuk dapat mengajar di kelas. Seorang guru tidak dapat mengajar dengan baik apabila ia tidak memiliki kemampuan pedagogik.

Seorang guru hendaknya memenuhi persyaratan mengajar dan mampu mengembangkan pembelajaran siswa yang efektif. Menurut Syah dan Kariadinata (2009), guru yang memiliki kemampuan mengajar yang baik mampu mengembangkan "Pembelajaran Aktif, Inovatif, Kreatif, Efektif, Menyenangkan, Gembira dan Berbobot (Paikem Gembrot)". Hal ini yang diharapkan dari guru SMAN yang ada di Kota Sekayu sehingga siswa menjadi nyaman mengikuti proses pembelajaran di sekolah.

Hasil observasi yang peneliti lakukan pada beberapa SMAN yang ada di Kota Sekayu menunjukkan kurang lebih $50 \%$ guru kompetensi pedagogiknya rendah. Hal ini dapat berdampak kepada kinerjanya dalam melaksanakan tugas mengajarnya yaitu merencanakan, melaksanakan, dan mengevaluasi proses pembelajaran serta sikapnya yang indisipliner. Keadaan ini menuntut adanya perbaikan kompetensi pedagogik guru. Hal serupa juga diungkapkan Gusman (2014). Guru yang kinerjanya rendah terlihat d ari (1) semangatnya yang kurang dalam menyelesaikan tugas yang berkaitan dengan perangkat pembelajaran, (2) program pengajarannya yang belumbaik, (3) kreativitasnya dalam memilih strategi dan metode pembelajaran yang rendah, dan (4) kepentingan pribadinya lebih besar daripada pelaksanaan tugas profesinya. Keadaan ini menunjukkan bahwa masih banyak guru SMA yang kompetensi mengajarnya belum memenuhi standar. Hal ini dapat berpengaruh pada keberhasilan pembelajaran. Berdasarkan uraian di atas, penelitian ini bertujuan untuk mengetahui pengaruh kompetensi pedagogik guru terhadap kualitas pembelajaran SMA Negeri di Kota Sekayu.

\section{METODE PENELITIAN}

Penelitian dilaksanakan di lima sekolah menengah atas negeri (SMAN) yang berada di Kota Sekayu, Kabupaten Musi Banyuasin, Provinsi Sumatera Selatan. Penelitian ini berlangsung selama enam bulan, dimulai dari bulan April 2020 dan berakhir pada bulan September 2020. Penelitian ini menggunakan metode survei yang pada umumnya dilakukan untuk mengambil suatu generalisasi dari pengamatan yang tidak mendalam (Sugiyono, 2007). Variabel yang diteliti yaitu pengaruh kompetensi pedagogik guru terhadap kualitas pembelajaran. 
Populasi penelitian ini adalah semua guru SMAN di Kota Sekayu yang berjumlah 162. Sampel merupakan sebagian atau wakil populasi yang akan diteliti, yang dalam penelitian ini diambil secara acak dengan teknik simple random sampling (Arikunto, 2013). Jumlah anggota sampel terpilih yaitu 102 reponden yang ditentukan menggunakan rumus Taro Yaname dan Slovin $n_{i}=\frac{N_{i}}{N} \cdot n$ dengan $n=\frac{N}{N \cdot d^{2}+1}$ dengan presisi yang ditetapkan 6\% (Riduwan, 2011).

Teknik pengumpulan data dalam penelitian ini dilakukan dengan menyebarkan angket, yaitu daftar pernyataan yang diberikan kepada orang lain yang bersedia memberikan respon sesuai dengan permintaan peneliti (Riduwan, 2013). Penyusunan instrumen melalui tahapan penyusunan kisi-kisi berdasarkan dimensi dan indikator masing-masing variabel, dilanjutkan dengan penyusunan dan pembuatan butir-butir pernyataan yang sesuai dengan indikator masing-masing variabel. Pengukurannya menggunakan skala Likert. Pengujian kelayakan instrumen penelitian dilakukan dengan uji validitas dan reliabilitas. Instrumen yang terbukti valid dan reliabel digunakan sebagai angket penelitian. Dimensi, indikator, dan jumlah butir pernyataan dalam instrumen untuk setiap variabel disajikan dalam tabel 1 berikut ini.

Tabel 1. Kisi-kisi instrumen penelitian

\begin{tabular}{|c|c|c|c|}
\hline Variabel & Dimensi & Indikator & Jumlah butir perny ataan \\
\hline \multirow{10}{*}{$\begin{array}{c}\text { Kualitas } \\
\text { Pembelajaran }(\mathrm{Y})\end{array}$} & Guru & - Pengua saan Ilmu Pen getahuan & 2 \\
\hline & & - KeterampilanMengajar & 3 \\
\hline & Siswa & - Keaktifan Siswa Belajar & 3 \\
\hline & & - KegiatanEkstrakurikuler & 2 \\
\hline & Iklim Kelas & - Sua sana Kela s Kondusif & 2 \\
\hline & & - Sua sana Kela s Nyaman & 3 \\
\hline & Kurikulum & - Kualita s Materi Pelajaran & 3 \\
\hline & & $\begin{array}{l}\text { - Kesesuaian Tujuan Pembelajaran } \\
\text { dengan Kompetensi }\end{array}$ & 2 \\
\hline & Sapras & - Ketersediaan Sa pras Belajar & 2 \\
\hline & & - Penggunaan Sa pras Belajar & 3 \\
\hline \multirow{15}{*}{$\begin{array}{c}\text { Kompetensi } \\
\text { Pedagogik Guru } \\
\left(\mathrm{X}_{1}\right)\end{array}$} & Pengetahuan & - Mengidentifikasi Kebutuhan & 2 \\
\hline & (Knowledge) & BelajarSiswa. & \\
\hline & & $\begin{array}{l}\text { - Melakukan Pembelajaran Sesuai } \\
\text { dengan Kebutuhan Siswa. }\end{array}$ & 2 \\
\hline & Pemahaman & - Memahami Karakteritik Siswa & 1 \\
\hline & (Understanding) & - Memahami Keinginan Belajar & \\
\hline & & Siswa. & 2 \\
\hline & $\begin{array}{l}\text { Kemampuan } \\
\quad(\text { Skill })\end{array}$ & $\begin{array}{l}\text { - Kemampuan Memilih Alat Peraga } \\
\text { - Kemampuan Membuat Alat }\end{array}$ & 2 \\
\hline & & Peraga. & 2 \\
\hline & Nilai (Value) & - Menanamkan Nilai-nilai Kejujuran & 2 \\
\hline & & Keterbukaan. & 2 \\
\hline & & - Menanamkan Nilai-nilai & \\
\hline & & Demokrasi. & 2 \\
\hline & Sikap (Attitude) & - Rea ksi terhadap Rangsangan dari & 2 \\
\hline & & Luar. & 1 \\
\hline & & • Rea ksiterhadap covid 19 & 1 \\
\hline
\end{tabular}




\begin{tabular}{|c|c|c|c|}
\hline Variabel & Dimensi & Indikator & Jumlah butir perny ataan \\
\hline & & - Pera saan terhadap Kenaikan Gaji & 2 \\
\hline & Minat (Interest) & $\begin{array}{l}\text { - Minat untuk Mempelajari Sesuatu } \\
\text { yang Baru }\end{array}$ & 2 \\
\hline & & - Minat Melanjutkan Pendidikan & 1 \\
\hline
\end{tabular}

Sebelum melakukan analisis data, dilakukan uji persyaratan analisis regresi. Pengujian ini dilakukan dengan uji normalitas, linieritas, dan uji asumsi klasik (Kesumawati \& Aridanu, 2017). Hasil pengujian menunjukkan data di semua variabel bersifat normal, linier, dan memenuhi asumsi klasik. Dengan demikian, analisis data dengan regresi untuk pembuktian hipotesis dapat dilakukan. Teknik analisis regresi yang digunakan yaitu koefisien determinasi, uji siginifikansi (uji t) dan persamaan regresi linier sederhana.

\section{HASIL}

\subsection{Kualitas pembelajaran SMA Negeri di Kota Sekayu}

Hasil analisis deskriptif variabel kualitas pembelajaran dapat dilihat pada tabel 2 berikut ini.

Tabel2. Analisis frekuensi variabel kualitas pembelajaran $(Y)$

\begin{tabular}{|c|c|c|}
\hline & Statistics & \\
\hline Kualitas Pen & nbelajaran & \\
\hline & Valid & 102 \\
\hline & Missing & 0 \\
\hline Mean & & 109,1 \\
\hline & & 5 \\
\hline Std. Erroro & fMean & ,468 \\
\hline Median & & 109,0 \\
\hline & & 0 \\
\hline Mode & & 108 \\
\hline Std. Deviat & & 4,725 \\
\hline Variance & & 22,32 \\
\hline & & 5 \\
\hline Skewness & &,- 131 \\
\hline Std. Erroro & f Skewness & ,239 \\
\hline Kurtosis & &,- 248 \\
\hline Std. Erroro & f Kurtosis &, 474 \\
\hline Range & & 22 \\
\hline Minimum & & 98 \\
\hline Махітит & & 120 \\
\hline Sum & & 1113 \\
\hline & & 3 \\
\hline Percentil & 25 & 106,0 \\
\hline es & & 0 \\
\hline & 50 & 109,0 \\
\hline & & 0 \\
\hline & 75 & 112,2 \\
\hline & & 5 \\
\hline
\end{tabular}


Hasil jawaban responden untuk variabel kualitas pembelajaran $(Y)$ menunjukkan skor terendah 98 dan tertinggi 120, rata-rata 109.15, median 109.00, serta standar deviasi 4.725. Data tersebut menunjukkan selisih skor rata-rata 109.15 dan skor median 109.00 yang tidak melebihi satu simpangan baku 4.725. Ini berarti data kualitas pembelajaran SMAN di Kota Sekayu berdistribusi normal. Tabel 2 di atas menunjukkan bahwa $75 \%$ responden berhasil mengumpulkan nilai sebesar 112,25, sedangkan besar nilai maksimum 120. Jadi nilai 112,25 masih berada di atas nilai rata-rata 109,15. Dengan demikian, kualitas pembelajaran SMAN yang ada di Kota Sekayu berada dalam kategori baik.

\subsection{Kompetensi pedagogik guru SMAN di Kota Sekayu}

Hasil dari analisis deskriptif variabel kompetensi pedagogik guru dapat dilihat pada tabel 3 .

Tabel3. Ana lisis frekuensi va riabel kompetensi pedagogik guru $(X)$

\begin{tabular}{|c|c|c|}
\hline \multicolumn{3}{|c|}{$\begin{array}{l}\text { Statistics } \\
\end{array}$} \\
\hline \multicolumn{3}{|c|}{ Kompetensi Pedagogik Guru } \\
\hline $\mathrm{N}$ & Valid & 102 \\
\hline & Missing & 0 \\
\hline Mean & & $\begin{array}{r}117, \\
88\end{array}$ \\
\hline \multicolumn{2}{|c|}{ Std.Error of Mean } & 691 \\
\hline \multicolumn{2}{|c|}{ Median } & $\begin{array}{r}117, \\
00\end{array}$ \\
\hline \multicolumn{2}{|l|}{ Mode } & 116 \\
\hline \multicolumn{2}{|c|}{ Std.Deviation } & $\begin{array}{r}6,97 \\
7\end{array}$ \\
\hline \multicolumn{2}{|l|}{ Variance } & $\begin{array}{r}48,6 \\
79\end{array}$ \\
\hline \multicolumn{2}{|l|}{ Skewness } & ,067 \\
\hline \multicolumn{2}{|c|}{ Std.Error of Skewness } & ,239 \\
\hline \multicolumn{2}{|c|}{ Kurtosis } & $\begin{array}{r}- \\
, 111\end{array}$ \\
\hline \multicolumn{2}{|c|}{ Std. Error of Kurtosis } & ,474 \\
\hline \multicolumn{2}{|c|}{ Range } & 34 \\
\hline \multicolumn{2}{|l|}{ Minimum } & 100 \\
\hline \multicolumn{2}{|l|}{ Махітит } & 125 \\
\hline \multirow{2}{*}{\multicolumn{2}{|c|}{ Sum }} & 120 \\
\hline & & 24 \\
\hline \multirow[t]{3}{*}{$\begin{array}{l}\text { Percentil } \\
\text { es }\end{array}$} & 25 & $\begin{array}{r}114, \\
00\end{array}$ \\
\hline & 50 & $\begin{array}{r}117, \\
00\end{array}$ \\
\hline & 75 & $\begin{array}{r}123, \\
00\end{array}$ \\
\hline
\end{tabular}


Jawaban responden untuk kompetensi pedagogik guru (X) SMA Negeri di Kota Sekayu menghasilkan skor terendah 100 dan tertinggi 125, rata-rata 117.88, median 117.00, serta standar deviasi 6.977. Ini berarti selisih skor rata-rata 117.88 dan skor median 117.00 tidak melebihi satu simpangan baku 6.977. Hal ini menunjukkan bahwa frekuensi data kompetensi pedagogik guru SMAN di Kota Sekayu berdistribusi normal. Tabel 3 juga menjelaskan bahwa $75 \%$ responden berhasil mengumpulkan nilai 123,00 sedangkan nilai maksimum yang berhasil diperoleh dari responden adalah 125, dan nilai rata-rata sebesar 117,88. Jadi nilai 123,00 berada di atas nilai rata-rata 117,88. Dengan demikian, kompetensi pedagogik guru SMA Negeri di Kota Sekayu sudah baik.

\subsection{Pengaruh kompetensi pedagogik guru terhadap kualitas pembela jaran}

Hipotesis penelitian ini yaitu kompetensi pedagogik guru berpengaruh signifikan terhadap kualitas pembelajaran. Hasil penghitungannya dapat dilihat dari output pada tabel 4.

Tabel4. Ha sil analisis koefisien determinasi $X-Y$

\begin{tabular}{ccccc}
\hline \multicolumn{5}{c}{ Model Summary } \\
\hline Model & $\mathrm{R}$ & R Square & $\begin{array}{c}\text { Adjusted R } \\
\text { Square }\end{array}$ & $\begin{array}{c}\text { Std. Error of } \\
\text { the Estimate }\end{array}$ \\
\hline 1 &, $543^{\mathrm{a}}$ &, 295 &, 288 & 3,987 \\
\hline
\end{tabular}

a. Predictors: (Constant), Va riabelX

Tabel 4 menunjukkan nilai $R$ untuk kompetensi pedagogik guru sebesar $0,543^{\text {a }}$. Ini berarti korelasi antara kompetensi pedagogik guru $(X)$ dengan nilai kualitas pembelajaran $(Y)$ menunjukkan kategori hubungan yang “sedang” karena berada pada rentang 0,400 - 0,599. Hal ini didasarkan pada pedoman interpretasi koefisien korelasi (Sugiyono, 2014). Pengujian pengaruh variabel kompetensi pedagogik guru $(X)$ terhadap kualitas pembelajaran $(Y)$ dapat dilihat dari koefisien determinasi $\left(R^{2}\right)$. Tabel 4 menunjukkan nilai $R^{2}$ sebesar 0.295 yang berada pada kategori “sedang" karena berada pada rentang $0,10-0,29$ padakategori pengaruh variabel yang diteliti (Suwarno, 1988). Dengan demikian, pengaruh variabel kompetensi pedagogik terhadap kualitas pembelajaran guru termasuk dalam kategori sedang, sebesar $29.5 \%$.

Selanjutnya, untuk mengetahui apakah kompetensi pedagogik guru berpengaruh signifikan terhadap kualitas pembelajaran dilakukan uji t atau uji signifikansi. Hasil analisis uji signifikansi korelasi kompetensi pedagogik guru dengan kualitas pembelajaran disajikan dalam tabel 5. 
Tabel5. Hasil Uji $t$ variabel $X-Y$

\begin{tabular}{|c|c|c|c|c|c|}
\hline \multirow[t]{2}{*}{ Model } & \multicolumn{2}{|c|}{$\begin{array}{l}\text { Unstandardized } \\
\text { Coefficients }\end{array}$} & \multirow{2}{*}{$\begin{array}{c}\text { Standardize } \\
\text { Coefficients } \\
\text { Beta }\end{array}$} & \multirow[t]{2}{*}{$\mathbf{t}$} & \multirow[t]{2}{*}{ Sig. } \\
\hline & B & Std. Error & & & \\
\hline 1 (Constant) & 65,779 & 6,714 & & 9,797 & 000 \\
\hline VariabelX &, 368 &, 057 &, 543 & 6,471 & 000 \\
\hline
\end{tabular}

Tabel 5 menunjukkan nilai $t$ sebesar 6,471 dengan taraf signifikan 0,000. Nilai tersebut merupakan nilai $t_{\text {hitung }}$, yang kemudian dibandingkan dengan nilai $t_{\text {tabel }}$. Nilai $t_{\text {tabel }}$ pada tabel statistik dengan signifikansi 0,05:2=0,025 pada derajat kebebasan $(d f)=n-k$ atau $102-2$ $=100(\mathrm{n}=$ jumlah responden dan $k=$ jumlah variabel bebas $)$. Hasil yang diperoleh untuk $t_{\text {tabel }}$ sebesar 1.980. Jika $t_{\text {hitung }}>t_{\text {tabel }}$ dan nilai signifikansi $<0,005$, maka $\mathrm{H}_{\mathrm{o}}$ ditolak dan $\mathrm{H}_{\mathrm{a}}$ diterima. Nilai $t_{\text {hitung }} 6.471>1.980$ dan nilai signifikansi $0.000<0,005$ yang berarti $\mathrm{H}_{\mathrm{o}}$ ditolak dan $\mathrm{H}_{\mathrm{a}}$ diterima. Kesimpulannya kompetensi pedagogik guru berpengaruh secara signifikan terhadap kualitas pembelajaran SMAN di Kota Sekayu.

Penentuan persamaan regresi linier sederhana didasarkan pada tabel 5 dengan melihat data pada kolom unstandardized coefficients bagian " $\mathrm{B}$ ” dengan rumusan $\mathrm{Y}=\mathrm{a}+\mathrm{bX}$. Nilai a diperoleh dari nilai constant sedangkan nilai b diperoleh dari nilai kompetensi pedagogik guru. Persamaan regresi liniernya dapat dituliskan sebagai berikut: $\mathrm{Y}=65.779+0.368 \mathrm{X}_{2}+\mathrm{e}$. Interpretasi atas nilai konstanta sebesar 65.779 yaitu kompetensi pedagogik guru nol. Nilai kualitas pembelajaran sebesar 65.779. Nilai kompetensi pedagogik guru (X) sebesar 0,368. Ini berarti peningkatan satu satuan variabel kompetensi pedagogik guru akan meningkatkan kualitas pembelajaran sebesar 65.779 satuan dengan asumsi variabel kompetensi pedagogik guru konstan.

\section{PEMBAHASAN}

\subsection{Kualitas pembelajaran SMAN di Kota Sekayu}

Variabel pertama yang dianalisis adalah variabel terikat yaitu kualitas pembelajaran. Berdasarkan jawaban responden, kualitas pembelajaran SMAN di Kota Sekayu termasuk dalam kategori "baik". Hal ini dapat dilihat dari distribusi frekuensi di mana 75\% responden menghasilkan nilai 112,25 dari nilai maksimum sebesar 120. Jadi, nilai 112,25 masih berada di atas nilai rata-rata 109,15. Dengan demikian, kualitas pembelajaran di SMAN di Kota Sekayu berada dalam kategori baik.

Kualitas pembelajaran saat ini menjadi perhatian serius dari semua pihak, baik pemerintah, lembaga pendidikan, maupun masyarakat. Di era globalisasi, sekolah yang tidak 
berkualitas akan ditinggalkan oleh masyarakat. Upaya mencapai pembelajaran yang berkualitas membutuhkan dukungan berbagai faktor yaitu sarana dan prasarana yang memadai, pembiayaan pendidikan yang cukup, kurikulum yang fleksibel, tenaga kependidikan yang berkompeten, dan input yang memenuhi standar. Artinya, kualitas pembelajaran bukan hanya memenuhi delapan standar nasional pendidikan. Murkoni (2017) mengatakan bahwa secara simultan kualitas pembelajaran dilihat dari aspek perencanaan, pelaksanaan dan penilaian berpengaruh terhadap kepuasan siswa.

Tujuan akhir kegiatan pembelajaran di lembaga pendidikan yaitu memperoleh hasil belajar yang dapat digunakan untuk melanjutkan pendidikan atau memasuki kerja.dunia. Hasil belajar tersebut dipengaruhi oleh faktor internal dan faktor eskternal (Slameto, 2007). Faktor internal adalah faktor yang berasal dari diri siswa itu sendiri meliputi motivasi, kecerdasan intelegensi, kesehatan, dan kesiapan belajar. Faktor eksternalnya yaitu guru-guru yang professional, dukungan sarana dan prasarana belajar, orang tua, biaya, ketersediaan ICT (Information Computer dan Technology) dan penggunaannya. Dari semua itu, kehadiran seorang guru dalam proses pembelajaran tidak bisa diabaikan (Harapan, 2007). Artinya, ketersediaan guru yang berkualitas merupakan faktor penting dan kunci sukses dalam proses belajar-mengajar. Guru selaku tenaga pendidik harus tersedia di setiap lembaga pendidikan. Ini sejalan dengan pendapat Nandika (2007) yang mengatakan bahwa "pendidikan bukan sekedar mengajar atau mentransfer pengetahuan dan mengembangkan aspek intelektual, melainkan juga mengembangkan karakter, moral, nilai-nilai, dan budaya peserta didik." Hasil pembelajaran itu oleh karenanya meliputi tiga aspek yaitu kemampuan kognitif, afektif, dan psikomotor (Sudjana, 2004).

\subsection{Kompetensi pedagogik guru SMAN di Kota Sekayu}

Penelitian ini juga melakukan analisis variabel bebas, yaitu kompetensi pedagogik guru. Jawaban yang diberikan oleh responden menunjukkan bahwa kompetensi pedagogik guru SMAN di kota Sekayu termasuk dalam kategori "baik". Hal ini dapat dilihat dari distribusi frekuensi, dimana 75\% responden menghasilkan nilai sebesar 123,00 dimana nilai maksimalnya sebesar 125 , dan nilai rata-ratanya sebesar 117,88. Jadi, nilai 123,00 berada di atas nilai rata-rata (mean) 117,88. Dengan demikian, kompetensi pedagogik guru SMAN di Kota Sekayu sudah baik.

Kompetensi pedagogik guru-guru SMAN di Kota Sekayu tidak cukup hanya diukur dari penguasaan ilmu pengetahuan, pemahaman materi mengajar, keterampilan mengajar, nilai 
yang dianut, sikap terhadap pelajaran, dan minat pada mata pelajaran. Masih banyak dimensi lain yang mempengaruhi kemampuan pedagogik guru. Hasil pen elitian ini bertolak belakang dengan penelitian yang dilakukan Habibullah (2012). Ia menemukan bahwa kompetensi pedagogik guru pada aspek kemampuan pengetahuan pembelajaran dalam kategori "kurang", pengetahuan pengembangan potensi peserta didik dan upaya reflektif untuk meningkatkan kualitas pembelajaran dalam kategori "sangat kurang”, kemampuan menyusun RPP dalam kategori "cukup", pengorganisasian materi ajar dan evaluasi berada pada kategori "kurang" dan kemampuan guru melaksanakan pembelajaran dalam kategori “cukup”.

Penelitian Balqis, dkk. (2014) menunjukkan bahwa (1) kompetensi guru merencanakan pembelajaran dilakukan dengan membuat draf RPP. Namun, sebagian guru tidak membawa RPP pada saat proses belajar mengajar berlangsung sehingga tujuan pembelajaran tidak tercapai secara maksimal; (2) kompetensi guru melaksanakan pembelajaran dilakukan dengan mendalami dan memantapkan sejumlah materi pembelajaran sebagaimana terdapat dalambuku paket. Namun, dalam prosesnya, kemampuan guru mengelola kelas kurang baik. Guru juga kurang disiplin dalam pemanfaatan waktu; dan (3) kompetensi guru memotivasi siswa untuk belajar dilakukan dengan memberi kesempatan kepada peserta didik untuk terlibat aktif dalam menggunakan fasilitas teknologi informasi dan komunikasi, berkomunikasi secara efektif dengan peserta didik, dan melakukan tindakan reflektif.

\subsection{Pengaruh kompetensi pedagogik guru terhadap kualitas pembelajaran}

Hasil penelitian menunjukkan kompetensi pedagogik guru SMAN di Kota Sekayu berpengaruh signifikan terhadap kualitas pembelajaran. Hasil uji hipotesis menunjukkan bahwa kompetensi pedagogik guru berpengaruh signifikan terhadap kualitas pembelajaran. Secara parsial, pengaruh variabel kompetensi pedagogik terhadap kualitas pembelajaran di semua SMAN di Kota Sekayu pada saat ini termasuk dalam kategori "sedang", yaitu 0.295 (29,5\%). Nilai sebesar ini setelah dikonfirmasikan dengan tabel koefisien (Suwarno, 1988).

Bagi seorang guru, kompetensi merupakan modal utama melaksanakan tugas-tugas pengajaran. Setiap orang yang akan menerjunkan dirinya ke dalam profesi pendidikan harus membekali dirinya empat kompetensi, yaitu kompetensi pedagogik, kompetensi profesional, kompetensi sosial, dan kompetensi kepribadian. Guru yang kurang profesional dalam menjalankan profesinya akan lemah dalam melaksanakan tugas pedagogiknya. Berdasarkan uraian tersebut, ada pengaruh kompetensi pedagogik guru terhadap kualitas pembelajaran 
SMAN di Kota Sekayu. Pengaruh yang diberikan termasuk dalam kategori sedang. Oleh karenanya, kompetensi ini masih perlu ditingkatkan.

\section{SIMPULAN}

Penelitian ini menunjukkan bahwa kompetensi pedagogik guru berpengaruh pada kualitas pembelajaran SMAN di Kota Sekayu. Pengaruhnya termasuk dalam kategori sedang. Hasil penelitian ini diharapkan dapat meningkatkan kualitas pembelajaran hingga pada titik maksimal. Kualitas pembelajaran pada semua SMAN yang ada di kota Sekayu masih dapat ditingkatkan dengan memperbaiki unsur kepemimpinan, inovasi, motivasi, pelaksanaan administrasi, pelaksanaan supervisi, dan pelaksanaan kewirausahaan. Selain itu, guru tidak cukup mengandalkan satu kompetensi saja. Mereka juga harus memiliki berbagai kompetensi yang lainnya yang dibutuhkan untuk mengembangkan proses pembelajaran yang efektif.

Berdasarkan hasil penelitian dapat disarankan beberapa hal sebagai berikut. Pihak sekolah diharapkan perlu meningkatkan atau memperbaiki kualitas pembelajarannya. Guruguru diharapkan terus meningkatkan kompetensinya sehingga dapat meningkatkan kualitas pembelajaran di sekolah masing-masing. Siswa secara mandiri dapat meningkatkan kualitas pembelajarannya. Orang tua dapat memberikan perhatian yang lebih kepada anak-anak mereka selama mengikuti proses pembelajaran di sekolah. Orang tua berkewajiban mendukung sarana dan prasarana belajar di rumah, memberikan gizi yang cukup, menjaga kesehatan dan perhatian kepada setiap anak. Pemerintah melalui Dinas Pendidikan dan Kebudayaan Provinsi Sumatera Selatan dapat menyediakan atau memenuhi fasilitas belajar di sekolah, memberikan dana yang cukup, dan memberikan perhatian serta pengawasan pendidikan di tingkat sekolah menengah.

\section{DAFTAR PUSTAKA}

Arikunto, S. (2013). Prosedur penelitian. Jakarta: Rineka Cipta.

Balqis, P., Ibrahim, B.U., \& Ibrahim, S. (2014). Kompetensi pedagogik guru dalam meningkatkan motivasi belajar siswa SMP Negeri 3 Ingin Jaya kabupaten Aceh Besar. Jurnal Administrasi Pendidikan Program Pascasarjana Unsyiah, 2(1). 25-38.

Gusman, H. E. (2014). Hubungan gay a kepemimpinan kepala sekolah dan kinerja guru di SMP N Kecamatan Palembayan Kabupaten Agam. Bahana Manajemen Pendidikan Jurnal Administrasi Pendidikan. 2(1). 1-9.

Habibullah. (2012). Perbandingan hasil belajar siswa boarding dan nonboarding dala m mata pelajaran seni budaya di SMA Negeri 9 Banda Aceh. Banda Aceh: Universitas Syiah Kuala.

Harapan, E. (2007). Fakor-faktor determinan yang mempengaruhi profesionalisme dosen. Bandung: UPI Bandung.

Kesumawati, N., \& Aridanu, I. (2017). Statistik parametrik penelitian pendidikan. Palembang. Noer Fikri. 
Murkoni, S. (2017). Pengaruh kualitas pembelajaran guru ekonomi terhadap kepuasan siswa di SMA Negeri 2 Sentajo Raya. Pebkis Jurnal. 9(2). 140-150.

Nandika, D. (2007). Pengantar pendidikan. Jakarta: Rineka Cipta.

Peraturan Pemerintah Nomor 19 tahun 2005 tentang Standar Nasional Pendidikan (SNP).

Riduwan. (2011). Dasar-dasar statistik. Bandung: Alfabeta.

Riduwan. (2013). Belajar mudah penelitian untuk guru-karyawan dan penelitian pemula. Bandung: Alfabeta.

Saifulloh, dkk. (2012). Strategi peningkatan mutu pendidikan di sekolah. Jurnal Sosial Humaniora (JSH). 5(2). 206-218.

Slameto. (2007). Faktor-faktor yang mempengaruhi profesionalisme guru. Jakarta: Rineka Cipta.

Sudjana, N. (2004). Dasar-dasar proses belajar mengajar. Bandung: PT. Remaja Rosda Karya.

Sudrajat, A. (2008). Pengertian, pendekatan, strategi, metode dan model pembelajaran. Bandung: Sinar Baru Algensindo.

Sugiyono. (2007). Metode penelitian administrasi. Bandung: Alfabeta.

Sugiyono. (2014). Metode penelitian pendekatan kuantitatif, kualitatif dan $R \& D$. Bandung: Alfabeta.

Suwarno, B. (1988). Pengantar aplikasi statistik dalam penelitian pendidikan. Bandung: UPI Bandung.

Syah, M., \& Kariadinata, R. (2009). Pembelajaran aktif, inovatif, kreatif, efektif dan menyenangkan (PAIKEM). Bandung: UIN Sunan Gunung Jati.

Undang-undang Nomor 14 tahun 2005 tentang Guru dan Dosen. 